\title{
The Global Development of Halal Food Industry: A Survey
}

\author{
Rininta Nurrachmi ${ }^{1}$
}

\begin{abstract}
This study aims to observe the existence of Halal food industry in developed and developing countries, and ways to increase the acceptance towards Halal products from nonMoslem societies. The approach is based on observation of the business environment of Halal food industry, online research and analysis of papers in journals. The finding indicates that although developed countries have less Moslem but the market share for Halal food is high. Countries with less Moslem population namely Thailand, United Kingdom and Australia can capture the opportunity of Halal food in the global market. Thus, most of Halal food exporters are coming from there. Halal food industry can be a catalyst to develop other potential sectors who get the negative impact from economic crisis in a country with less Moslem population. Countries namely Thailand, Australia, United Kingdom and Japan have applied commercial farm in their supply management to support their Halal food production. Furthermore, the awareness of consuming Halal food also come from non-Moslem due to the safer and freshness of the food. Hence it is important for producer to promote Halal food as being safety-compliant.
\end{abstract}

Keywords: Halal Food, Halal Industry, Developed and Developing Countries

\begin{abstract}
Abstrak. Tujuan dari penelitian ini untuk mengamati keberadaan industri makanan Halal di negara-negara maju dan berkembang. Selain itu solusi apa yang bisa dilakukan untuk meningkatkan penerimaan masyarakat non-Muslim terhadap produk-produk Halal. Pendekatan penelitian yang digunakan yaitu pengamatan dari usaha industri makanan Halal, analisis penelitian ilmiah dari jurnal, internet dan diskusi dengan rekan peneliti selama satu tahun. Penelitian ini menunjukkan bahwa walaupun populasi muslim di negara maju lebih sedikit tetapi permintaan pasar untuk produk makanan Halal tinggi. Negara-negara dengan jumlah populasi muslim yang sedikit seperti Thailand, Inggris dan Australia dapat melihat kesempatan akan meningkatnya kebutuhan makanan Halal di pasar dunia sehingga mayoritas negara mengekspor makanan Halal dari negara-negara tersebut. Industri makanan Halal dapat menjadi katalis pengembangan potensi sektor lain yang mendapat akibat negatif karena krisis ekonomi pada negara-negara dengan minoritas muslim. Untuk mendukung produksi makanan Halalnya, negara-negara seperti Thailand, Australia, Inggris dan Jepang sudah mengembangkan pertanian berskala komersial dalam system penawaran produknya. Selain itu, pemahaman akan pentingnya mengkonsumsi makanan Halal juga disadari dari konsumen non-Muslim. Hal ini dikarenakan kesegaran dan keamanan dari produk makanannya. Sehingga penting sekali bagi produsen untuk mempromosikan makanan Halal yang proses pengolahannya terjaga dengan baik.
\end{abstract}

Kata kunci: Makanan Halal, Industri Halal, Negara-negara Maju dan Berkembang

\footnotetext{
${ }^{1}$ International Islamic University Malaysia | rini.martam@gmail.com
} 


\section{Introduction}

Halal industry is the latest trend in the world market. With Moslem population reaching 3 billion people, Halal industry becomes one of the fastest growing businesses in the global market. It covers sector such as finance, tourism, service, transportations, and food. Food is the essential thing in human life and the market potential for Halal food is very promising with Islam as the fastest growing religion in the world (Ismail, 2015).

Halal food market is one of the largest consumer markets in the world as reported by the Stated of The Global Islamic Economy Report in Thomson Reuters (2014). Furthermore, Moslems spent 16.6 percent of the total global food expenditure which eventually cause the Halal food market as one of the largest food markets in the world. Previous studies (see Regenstein et al., 2003; Lever and Miele, 2012; Abdul-Talib and Abd-Razak, 2013) indicate that the emergence of Halal in the global market is contributed by the growing global Moslem population. The growth of global Moslem population will experience a 35 percent increment from 1.6 billion in 2010 to 2.2 billion people in 2030 (The Pew Research Center, 2011). Hence the Halal food market will continue to dominate the global food market due to Moslems have to consume Halal food regardless whether they live within Moslem majority or minority societies (Razzaque and Chaudhry, 2013).

Nowadays, the awareness of consuming Halal food is not only come from Moslem but also non-Moslem because they think it is safer to purchase Halal products. Besides that, focus on shelf life and freshness needed for food is the reason why Halal food industry is very attractive. This condition boosted the emergence and growth of Halal food market with the broad acceptance among non-Moslem consumers who consider Halal food as safe, hygienic, quality and wholesome product. This opportunity has been grabbed by developed countries such as Japan, United Kingdom and Australia who mostly depend on automotive and electronic manufacturing. They assume that Halal 
food segment is the catalyst in developing other potential sectors that are affected negatively from the economic turmoil.

The largest Moslem nations are located in Asian countries and they are rich with natural resources namely oil, gas, agricultural and food. Developing countries namely Malaysia, Indonesia and Thailand who are boosting their Halal industry have the potential power to become Halal center. However, Hasan and Awang (2009) report that most of Halal food exporters come from non-Moslem countries such as Australia, Canada, France and New Zealand who has less Moslem population. This condition indicates that developed countries who export Halal food are well aware of the importance of Halal business because eventually the Halal niche market contributes significantly to their country's revenue. This paper addresses the emerging market of Halal food industry in developed and developing countries. Other than that, the paper seeks ways to increase non-Moslem societies' acceptance towards Halal products.

The remaining part consists of three sections. Introduction and research objective are elaborated in the beginning. The next section reviews literatures, methodology, discussion and analysis. The discussion and analysis part cover the terms of Halal, Halal food industry and ways to increase non-Moslem societies' acceptance towards Halal products. In part three, conclusion and recommendation sums up the whole paper. Lastly, references list all sources supporting the writing process.

\section{Literature Review}

Halal is Arabic word which mean permitted and lawful. It is not only related to consumption but also all actions. While haram means prohibited and unlawful. In the Holy Quran the difference between Halal and haram is clearly stated in Surah Al-A'raf [7]: 157 
"Those who follow the messenger, the unlettered prophet, whom they find written in what they have of the Torah and the Gospel, who enjoins upon them what is right and forbids them what is wrong and makes lawful for them the good things and prohibits for them the evil and relieves them of their burden and the shackles which were upon them. So they who have believed in him, honored him, supported him and followed the light which was sent down with him - it is those who will be the successful." (Al-A'raf [7]: 157)

The foundation of religious obligation has directed people behavior, whereas in Islam each Moslem acts according Quran and Sunnah in every aspect of their lives. Islam emphasizes the importance of Halal in every aspect of Moslem's life especially on food consumption and dietary requirement (Bergeaud-Blackler, 2007; Tieman and Hassan, 2015). The term Halal generally relates to permissible consumption of food as well as moral and ethical conduct. In the past 4 years the term Halal has attracted much attention. As we can see there are research about Moslem consumers who ensure that what they eat come from Halal source (Omar and Zahrain, 2012; Batu and Regenstein, 2014; Hayat et al., 2015). The Moslem consumers do not only check the ingredients but also wanted to be notified that the whole processes are in accordance with the Sharia principles.

The scope of Halal food and beverage is not only related to pork free product and alcohol. Carnivorous animals, amphibians (frogs and mangrove crabs) and all insects exclude grasshoppers are not Halal. Meat from permissible animals such as poultry and cattle must be slaughter according to Islamic law and render them Halal. There should be standardization in hygiene and sanitation for Halal food and it must not be harmful for health.

The verses in Quran clearly stated about the prohibited food and meat that should not be consumed for Moslem in Al-Baqarah [2]: 173, Al-Maidah [5]: 3, Al-An'am [6]: 145 and An-Nahl [16]: 115 
"He has only forbidden to you dead animals, blood, the flesh of swine, and that which has been dedicated to other than Allah. But whoever is forced [by necessity], neither desiring [it] nor transgressing [its limit], there is no sin upon him. Indeed, Allah is Forgiving and Merciful."(Al-Baqarah [2]: 173)

"Prohibited to you are dead animals, blood, the flesh of swine, and that which has been dedicated to other than Allah, and [those animals] killed by strangling or by a violent blow or by a head-long fall or by the goring of horns, and those from which a wild animal has eaten, except what you [are able to] slaughter [before its death], and those which are sacrificed on stone altars, and [prohibited is] that you seek decision through divining arrows. That is grave disobedience. This day those who disbelieve have despaired of [defeating] your religion; so fear them not, but fear Me. This day I have perfected for you your religion and completed My favor upon you and have approved for you Islam as religion. But whoever is forced by severe hunger with no inclination to sin - then indeed, Allah is Forgiving and Merciful." (Al-Maidah [5]: 3)

Say, "I do not find within that which was revealed to me [anything] forbidden to one who would eat it unless it be a dead animal or blood spilled out or the flesh of swine - for indeed, it is impure - or it be [that slaughtered in] disobedience, dedicated to other than Allah. But whoever is forced [by necessity], neither desiring [it] nor transgressing [its limit], then indeed, your Lord is Forgiving and Merciful." (Al-An'am [6]: 145)

"He has only forbidden to you dead animals, blood, the flesh of swine, and that which has been dedicated to other than Allah. But whoever is forced [by necessity], neither desiring [it] nor transgressing [its limit] - then indeed, Allah is Forgiving and Merciful". (An-Nahl [16]: 115) 
Batu and Regenstein (2014) stated that when preparing Halal food the process should be according to Islamic rules and the product integrity is maintain throughout the supply chain. Everything relates to the food preparation, handling and packaging must be Halal. Furthermore, Omar and Zahrain (2012) mentioned that when producing Halal food it should start from the farm and the food must be nutritious and prepare with permissible ingredients in clean and hygienic manner. Contamination from najs (filth as defined by Islamic law) or prohibited (haram) elements also cause the food becomes non-Halal. Beside production process, logistics and packaging are vital too. Non-Halal and Halal goods must be stored separately in order to prevent contamination.

\section{Method}

Qualitative method is applied in this study. The approach is based on observation in the business environment of Halal food industry, online research, analysis of papers from journals and brainstorming with coresearchers for one year from 2015 to 2016. Moreover, previous works are surveyed related to Halal food industry in developed and developing countries.

Malaysia, Indonesia and Thailand are selected as developing countries for this paper because these countries represent the emerging market and the prominent players for Halal food industry in South East Asia. While the United Kingdom, Australia and Japan as the developed countries because these countries receive high revenue and conducted a massive promotion for Halal food industry.

\section{Result and Discussion}

\section{Halal Food Industry in Developed and Developing Countries}

Islam has become the fastest growing religion in the world. The population of Moslem among the OIC (Organization Islamic Committee) members comprises of Asia (805 million), Africa (300 million) and Middle East 
(210 million) (Wacharajirasophon, 2016). With the growth of Halal food in the global market, the statistic indicates that the largest Moslem nations are located in Asian countries with $63.3 \%$ of the total Halal market.

Developed countries such as Japan, Australia and United Kingdom present a high demand for Halal products that suit a convenience-oriented lifestyle. As state in table 1, the market size for Halal food in 2014 has achieve USD 1 million. The consumers are not only come from Moslem, other religions also purchase Halal foods due to perceptions that they are safer. The United Kingdom with Moslem population around 3 million has high consumption on Halal meat which is more than 6 million dollars possibly due to demand from non-Moslem (Ismail, 2015).

Hassan and Awang (2009) reported that most of Halal food products are manufactured by non-Moslem countries rather than Moslem countries such as Argentina, Canada, New Zealand, France, Brazil and Australia. These countries export Halal meat although they have Moslem as minority. Besides that, countries such as Australia, Brazil and United State have large Halal sector and their destination countries for Halal meat are mostly Organization Islamic Committee (OIC) members. It indicates that they clearly recognize that Halal niche market contribute to the country's revenue thus they are well aware on the importance of Halal food business.

The author chooses Japan, Australia and United Kingdom as representation for developed countries while for developing countries comprise of Malaysia, Indonesia and Thailand. The reason is the accessible information on those countries. Although the number of Moslem in developed countries is below $5 \%$ from their total population, the Halal food industry is growing very fast. The increasing interest of Halal food from non-Moslem countries due to demand from consumers who believe food should be cleaner, hygiene, and better, as a result non-Moslem consumer began to look for Halal food as something positive.

The ecosystem of Australia and United Kingdom is on Halal red meat production with market size more than USD 1 million in 2014. While Japan 
focus on providing Halal food in university canteen, international airport, and restaurant. Countries in Organization Islamic Committee (OIC) and ASEAN are target for Halal food export because mostly Moslem nation located in that area.

Japan is one of a country who focuses to attract 1 million Moslem visitors a year. The upcoming 2020 Olympic Games held in Japan is an opportunity to attract Moslem tourists. To boost tourist visitor Japan apply free issuing visa for Indonesia, Malaysian and Thai because as we can see 63\% Moslem tourist coming from Southeast Asia. As an alternative revenue, the local government offer subsidies up to USD 820 to restaurants that earn Halal certification. Other than that Japan held Halal Expo and has 120 exhibitors in 2016.

Table 1. Halal Food Industry in Selected Developed Countries

\begin{tabular}{|l|l|l|l|}
\hline Developed Countries & \multicolumn{1}{|c|}{ Japan } & \multicolumn{1}{c|}{ Australia } & \multicolumn{1}{c|}{ UK } \\
\hline Number of Moslem & $\begin{array}{l}0.14 \% \text { from 127.3 } \\
\text { million }\end{array}$ & 2.25\% from 23.1 million & $\begin{array}{l}4.8 \% \text { from 64.1 } \\
\text { million }\end{array}$ \\
\hline $\begin{array}{l}\text { Market size for Halal } \\
\text { Food Industry (2014) }\end{array}$ & $\begin{array}{l}\text { USD 888,352 } \\
\text { (JPY 120 million) }\end{array}$ & $\begin{array}{l}\text { USD 1,016 million } \\
\text { (AUD 1,420 million) }\end{array}$ & $\begin{array}{l}\text { USD 1,462 million (1 } \\
\text { billion UK pound) }\end{array}$ \\
\hline Source of Halal Food & Self-production & Self-production & Self-production \\
\hline Ecosystem & $\begin{array}{l}\text { Focus on providing } \\
\text { Halal food menu at } \\
\text { university, } \\
\text { international airport } \\
\text { Export Halal food \& } \\
\text { drink to ASEAN }\end{array}$ & $\begin{array}{l}\text { Focus on meat } \\
\text { production } \\
\text { Exporters for Halal red } \\
\text { meat to Organization } \\
\text { Islamic Committee } \\
\text { (OIC) countries }\end{array}$ & $\begin{array}{l}\text { Focus on meat and } \\
\text { poultry production }\end{array}$ \\
\hline $\begin{array}{l}\text { Supply Chain } \\
\text { Management }\end{array}$ & $\begin{array}{l}\text { Mostly Commercial } \\
\text { farms }\end{array}$ & $\begin{array}{l}\text { Mostly Commercial } \\
\text { farms }\end{array}$ & $\begin{array}{l}\text { Mostly Commercial } \\
\text { farms }\end{array}$ \\
\hline Halal Certification & $\begin{array}{l}\text { JHA uses JAKIM } \\
\text { Malaysia's standard }\end{array}$ & $\begin{array}{l}\text { Australia Government } \\
\text { Authorized Halal } \\
\text { Program (AGAHP) }\end{array}$ & $\begin{array}{l}\text { The Halal Food } \\
\text { Authority (HFA) }\end{array}$ \\
\hline
\end{tabular}

Sources: www.bt.com.bn; www.theguardian.com; www.boi.go.th; www.bangkokpost.com; www.salaamgateway.com; www.Moslempopulation.com; Minister of International Trade and Industry Malaysia (2015); Australian Government Department of Agriculture (2014); Mori (2014)

As the biggest meat exporters, Australia is recognized as a world leader in Halal meat production. The biggest importers of Australian Halal meat are Indonesia, Saudi Arabia and United Arab Emirate. The Organization Islamic Committee (OIC) countries are the export target for Halal meat and the value 
of Halal red meat and meat product exports have reach AUD 1,420 million in the year 2013-2014 (Australian Government Department of Agriculture, 2015). While in United Kingdom the number of Moslem population is only 4.8\% or around 3 million but the market size for Halal food in this country is high with USD 1,462 million.

Developing countries such as Indonesia and Malaysia are the highest Halal food consumption with Moslem population 248.5 million and 29.8 million respectively. Malaysia has move forward for Halal industry among other ASEAN members. Thailand is a country with less Moslems population the demand for Halal food has increased about 20\% annually (Wacharajirasophon, 2016). These three countries are rich with natural resources and have the capability to produce its Halal food. The ecosystem is mostly focused on products.

From the selected developing countries, undoubtedly Indonesia is the biggest markets in the Asia for Halal products. With more than 210 million Moslems, it is an opportunity that foreign firms cannot resist. Based on 2013 data, Indonesia is the highest country for Moslem consumer food consumption with US\$ 190 billion followed by Turkey and Pakistan (The Global Islamic Economy, 2015). As the target for Halal food industry from other countries, developing this industry is important due to two benefits which are to protect domestic consumer from consuming non-Halal products and to gain earnings from export of Halal food products (Ratanamaneichat and Rakkarn, 2013).

Malaysia is an emerging country who successfully developed its industry in Islamic banking and finance. Many countries such as Indonesia, Thailand, Bosnia, Nigeria, and Algeria refer to Malaysia as a hub for Islamic finance. With the durability of its industry, Malaysia is expanding its Halal industry into other sector such as Islamic tourism and Halal food. The strong platform to develop Halal food industry in Malaysia is conduct through workshop and education to produce compatible Human Resources (HR) and provide Halal standardization by JAKIM (Malaysian Halal board) which become the reference to Halal food certificate in Japan. Furthermore, for nearly 
15 years Malaysia regularly held Malaysian International Halal Showcase (MIHAS). In 2016 MIHAS welcomed over 22,000 traders visitors from more than 70 countries and generated record sales more than RM 1 billion for 600 exhibitors.

Although Thailand has the least Moslem population compare to Malaysia and Indonesia, the Thai government urge the development of Thai Halal food products to help boost export. As the fifth largest Halal food exporter in the global market, Thailand known as a country offering investors strong government support, rich agricultural resources, skilled labor and excellent infrastructure. Food processing is the core strength of Thai industry. In 2011 Thailand has exports Halal food to 57 Islamic countries and achieves approximately $\$ 6.8$ billion. The world demand for Halal food keeps increasing and has grown by $12.1 \%$ in 2012 (Wacharajirasophon, 2016).

Islam is not the main religion in Thailand however the government of Thailand had proposed to establish Thailand as a Halal food hub in 2003 as a purpose to develop product quality, certification, marketing strategies and to enhance competitiveness. The established relevant institutions are the Halal Standard Institute of Thailand (HSIT) and the Halal Science Center (HSC) at the Faculty of Allied Health Science of Chulalongkorn University as an effort to improve and promote Halal food in the domestic and global markets (Wacharajirasophon, 2016). Furthermore, to increase the export of Halal food, the government has emphasized to enrich Resource and Development sector and building the southern province of Thailand consist of Pattani, Yala, Narathiwat, Satun and Songkhla and the sea resort of Phuket into major production bases for Halal products in Thailand. According to Mohd Nawawi, et al (2017) Thailand has been listed as top tenth world biggest food exporting countries and exporting halal products to the world. Thus, this country has become the fast emerging Halal hub in the region. 
Table 2. Halal Food Industry in Selected Developing Countries

\begin{tabular}{|l|l|l|l|}
\hline \multicolumn{1}{|c|}{ Developing countries } & \multicolumn{1}{|c|}{ Malaysia } & \multicolumn{1}{c|}{ Indonesia } & \multicolumn{1}{c|}{ Thailand } \\
\hline Number of Moslem & $\begin{array}{l}60.4 \% \text { from 29.8 } \\
\text { million }\end{array}$ & $\begin{array}{l}88 \% \text { from 248.5 } \\
\text { million }\end{array}$ & $10 \%$ from 66.2 million \\
\hline $\begin{array}{l}\text { Market Size for Halal } \\
\text { Food Industry (2014) }\end{array}$ & $\begin{array}{l}\text { USD 267 million } \\
\text { (RM 1.1 billion) }\end{array}$ & $\begin{array}{l}\text { USD 191 billion } \\
\text { (IDR 2,604 trillion) }\end{array}$ & $\begin{array}{l}\text { USD 5 billion } \\
\text { (174,662 billion bath) }\end{array}$ \\
\hline Source of Halal Food & $\begin{array}{l}\text { Self-production } \\
\text { Natural resources }\end{array}$ & $\begin{array}{l}\text { Self-production } \\
\text { Natural resources } \\
\text { Imported meat }\end{array}$ & $\begin{array}{l}\text { Self-production } \\
\text { Natural resources }\end{array}$ \\
\hline Ecosystem & $\begin{array}{l}\text { Products and services } \\
\text { Proper institutional } \\
\text { framework }\end{array}$ & Products & $\begin{array}{l}\text { Focus on production on } \\
\text { canned food products } \\
\text { (food processing) }\end{array}$ \\
\hline $\begin{array}{l}\text { Supply Chain } \\
\text { Management }\end{array}$ & $\begin{array}{l}\text { Mostly small-scale } \\
\text { farms }\end{array}$ & $\begin{array}{l}\text { Mostly smallscale } \\
\text { farms }\end{array}$ & $\begin{array}{l}\text { Mostly commercial } \\
\text { farms }\end{array}$ \\
\hline Halal Certification & $\begin{array}{l}\text { Jabatan Kemajuan } \\
\text { Islam Malaysia } \\
\text { (JAKIM) }\end{array}$ & $\begin{array}{l}\text { Majelis Ulama } \\
\text { Indonesia (MUI) }\end{array}$ & $\begin{array}{l}\text { The Central Islamic } \\
\text { Committee of Thailand } \\
\text { (CICOT) }\end{array}$ \\
\hline
\end{tabular}

Sources: www.bt.com.bn; www.theguardian.com; www.boi.go.th; www.bangkokpost.com; www.salaamgateway.com; www.Moslempopulation.com; Minister of International Trade and Industry Malaysia (2015); Australian Government Department of Agriculture (2014); Mori (2014)

\section{Ways to Increase Non-Moslem Societies' Acceptance Towards Halal Products}

Halal food is not a religious obligation for non-Moslems, they consume Halal food for their own benefit such as food safety. Halal food is sometimes associated with healthy food. There are many ways to enhance the awareness of Moslem to consume Halal food and beverage. Mass media, internet and da'wah are the effective tools to convey the important of consuming Halal products. However, it will be difficult to increase non-Moslem societies' acceptance towards Halal products. Since the prejudice of Islamophobia broadcasted by the western media, some non-Moslem got the connotation that the revenue from Halal industry is to provide funding for terrorism. The following news in 2014 from the Guardian United Kingdom and Daily Mail Australia cover the stories. 
"...the word Halal is frequently freighted with controversy...."

"...stop slashing animals' throat in ritual slaughters for Halal and kosher meat, says new leader of Britain's vets...."

"... Jewish and Moslem slaughter methods were inhumane and warned that total ban might not be far off..."

(The Guardian United Kingdom, 18 May 2014)

"...Halal-certification is detrimental Australian values of freedom of speech and freedom of religion. An Aussie housewife claims to have discovered 'deception and corruption' within the food industry, campaigning to uncover the truth about the relationship between Islam and some of Australia's major food companies...."

(Daily Mail Australia, 29 December 2014)

The fact that food is the ultimate thing in human's life, the market potential is very promising for people although they come from different cultural backgrounds and religion. Mathew et al. (2014) mentioned that in today's society, the increase concerns over health promotes the acceptance on Halal food as it gives the perception consuming clean and hygienic food to promote a better health. The incidents of food poisoning for example by salmonella and e-coli have made the issue on food safety a major market concern. Therefore, it is important to promote Halal food as being safetycompliant since they undergo one of the safest methods of production. Thus, Halal food producers should consider this condition as a great opportunity to attract non-Moslem community as one of the target market.

The Halal certificate and including Halal logo on the food product are the important thing to apply because consumers today are more aware about the food they consumed. The Halal logo attached in the packaging can convince Moslem consumers that the product produced and prepared according to Islamic requirements. While for non-Moslem consumers, Halal logo 
acknowledge them that the food is prepared in the most hygienic way and clean to be consumed.

Empirical studies on non-Moslem awareness on Halal food are limited (see Mathew et al, 2014; Haque et al, 2015) but the result indicates that the nonMoslem consumers response positively towards Halal food. Both research conduct in Malaysia through survey. The intention for non-Moslem for food safety, animal welfare and environment friendliness are factors that influence non-Moslem consumer in Halal product purchase. The studies provide inputs for both academics and the industry food makers in understanding the perception of non-Moslem consumers towards the concept of Halal food products.

\section{Conclusion}

With the trend of Halal food in the global market, countries with Moslem minority are embracing this industry as alternative revenue. Developed countries such as Australia, Japan and United Kingdom enhance the Halal food industry as alternative revenue other than electronic and automotive manufacture. They assume that Halal food segment is a catalyst in developing other potential sectors who receive negative effect from economic turmoil.

With Moslem population less than 5\% in developed countries, Halal food is growing very fast. These three developing countries Australia, Japan and United Kingdom put Organization Islamic Committee (OIC) and ASEAN countries as Halal food export target. Most source of Halal food in developed and developing countries are focus on self-production. Countries such as Japan, Australia, UK and Thailand mostly applied commercial farm in their supply chain management while most farms in Indonesia and Malaysia are using small scale.

The awareness of consuming Halal food is not only come from Moslem but also non-Moslem because they think it is safer to purchase Halal products. Besides that, focus on shelf life and freshness needed for food. That is the reason 
why Halal food industry is very attractive. Therefore, it is important to promote Halal food as being safety-compliant since they undergo one of the safest methods of production. Likewise, more research work should be conducted to fill the gaps of Halal market development beside those six mentioned countries. The high demand of Halal food should provide benefit for consumers in terms of giving a safer product and obligatory for Moslem to consume Halal food.

\section{References}

Abdul-Talib, A.N. and Abd-Razak, I.S. (2013). Cultivating Export Market Oriented Behavior in Halal Marketing: Addressing The Issues and Challenges in Going Global. Journal of Islamic Marketing, Vol. 4(2): 187197.

Akyol, M. and Kilinç, O. (2014). Internet and Halal Tourism Marketing. International Periodical For The Languages, Literature and History of Turkish or Turkic, Vol. 9: 171-186.

Awan, H.M. Siddiquei, A.N and Haider, Z. (2015). Factors Affecting Halal Purchase Intention - Evidence From Pakistan's Halal Food Sector. Management Research Review, Vol. 38(6): 640-660. Available at: https:// doi.org/10.1108/MRR-01-2014-0022.

Batu, Ali and Regenstein, Joe. (2014). Halal Food Certification Challenges and Their Implications for Moslem Societies Worldwide. International Periodical for The Languages, Literature and History of Turkish or Turkic, Vol. 9: 111-130.

Bergeaud-Blackler, F. (2007). New Challenges for Islamic Ritual Slaughter: A European perspective. Journal of Ethnic and Migration Studies, Vol. 33(6): 965-980.

Cochrane, Paul (2016). Opportunities for Growth in Japan's Halal Food Sector. On 6 March 2016. Retrieved from: http:/ /www.Salaamgateway.com.

Hassan, S.H. et al. (2009). Influence of the Halal Certification Mark in Food Product Advertisement in Malaysia. The New Culture of food. Marketing Opportunity from Ethnic, Religious and Cultural Diversity, Vol. 243.

Hassan, W.M. and Awang, K.W. (2009). Halal Food in New Zealand Restaurants: An Explanatory Study. International Journal of Economics and Management, Vol. 3(2): 385-402

Haque, Ahasanul, et al. (2015). Non-Moslem Consumers' Perception Toward Purchasing Halal Food Products in Malaysia. Journal of Islamic 
Marketing, Vol. 6(1): 133-147. Available at: https://doi.org/10.1108/JIMA-04-2014-0033.

International Markets Bureau. (2011). Global Pathfinder Report Halal Food Trends. Market Indicator Report: 1-10. Canada.

Ismail, R.M. (2015). Global Issues and Challenges for The Halal Food Industry. Paper presented on China (Ningxia) International Cooperation Forum on Halal Food Certification on September 2015. Available at: doi:10.13140/RG.2.1.3096.5842.

Lever, J. and Miele, M. (2012). The Growth of Halal Meat Markets in Europe: An Exploration of The Supply Side Theory of Religion. Journal of Rural Studies, Vol. 28(4): 528-537.

Mathew, et al. (2014). Acceptance on Halal Food Among Non-Moslem Consumers. Procedia - Social and Behavioral Sciences, Vol. 121: 262-271. Available at: doi:10.1016/j.sbspro.2014.01.1127.

Matrade. (2015). Status of The Halal Industry. Presented for World Halal Summit on 10 March 2015 by YB Dato' Sri Mustapa Mohamed Minister of International Trade and Industry.

Mori, T. (2014). The Present Condition and The Subject of Halal in Japan, in Comparison with Malaysia. Unpublished Research Paper. University of Marketing and Distribution Sciences. Japan.

Omar, S and Zahrain, M. (2012). Positioning The Halal Food Industry: The Case of Malaysia. NIDA Case Research Journal, Vol. 4(8): 157-174.

Ratanamaneichat, C. and Rakkarn, S. (2013). Quality Assurance Development of Halal Food Products for Export to Indonesia. Procedia - Social and Behavioral Sciences, Vol. 88: 134-141. Available at: doi:10.1016/j.sbspro.2013.08.488.

Razzaque, M.A. and Chaudhry, S.N. (2013). Religiosity and Moslem Consumers' Decision-Making Process in A Non-Moslem Society. Journal of Islamic Marketing, Vol. 4(2): 198-217.

Regenstein, J.M., Chaudry, M.M. and Regenstein, C.E. (2003). The Kosher and Halal Food Laws. Comprehensive Reviews in Food Science and Food Safety, Vol. 2(3): 111-127.

Swerdloff, Alex. (2016). Why Japanese Chefs are Embracing Halal Food. Retrieved from: http://www.munchies.vice.com on 30 May 2016.

Thackray, Lucy. (2016). Woman Concerned about Groceries Funding Islamic Organization. Daily Mail Australia. 29 December 2014. Retrieved on 1 March 2016.

Thailand Board of Investment. (2012). Thailand's Ample Food Industry Sees Expanding Opportunities. On 30 April 2016. Retrieved from: http://www.boi.go.th /tir/issue/201205_22_5/42.htm. 
The Malaysian Institute of Economic Research (MIER). (2003). Halal Food Industry Deserves More Attention: 1-3.

Thomson Reuters (2014). State of the global Islamic economy 2014-2015 report. Available at: www.zawya.com/ifg-publications/.

Tieman, M. and Hassan, F.H. (2015). Convergence of Food Systems: Kosher, Christian and Halal. British Food Journal, Vol. 117(9): 2313-2327.

Wacharajirasophon, Usanee. (2016). Factors Influencing Consumer Intention to Purchase Halal Food among Moslems in Thailand. Unpublished Master Thesis, Department of Business Administration, Kulliyah of Economics and Management Science, International Islamic University Malaysia.

Walker, Martin, et al. (2007). Addressing The Moslem Market. Can You Afford Not to?. A.T. Kearney Inc.

Yusof, S. and Shutto, N. (2014). The Development of Halal Food Market in Japan : An Exploratory Study. Procedia - Social and Behavioral Sciences, Vol. 121: 253-261. Available at: doi:10.1016/j.sbspro.2014.01.1126. 